\title{
The Occurrence of Antibiotic Resistance Genes in an Urban River in Nepal
}

\author{
Ocean Thakali ${ }^{1}{ }^{(D}$, Sarmila Tandukar ${ }^{2}{ }^{\circledR}$, John P. Brooks ${ }^{3}$, Samendra P. Sherchan ${ }^{4}$, \\ Jeevan B. Sherchand ${ }^{5}$ and Eiji Haramoto ${ }^{2, *(1)}$ \\ 1 Environment and Social System Science Course, University of Yamanashi, 4-3-11 Takeda, Kofu, \\ Yamanashi 400-8511, Japan; othakali@gmail.com \\ 2 Interdisciplinary Center for River Basin Environment, University of Yamanashi, 4-3-11 Takeda, Kofu, \\ Yamanashi 400-8511, Japan; sar1234tan@gmail.com \\ 3 Genetics and Sustainable Agricultural Unit, Agricultural Research Service, U.S. Department of Agriculture, \\ 810 Highway 12 East, Mississippi State, MS 39762, USA; john.brooks@usda.gov \\ 4 Department of Global Environmental Health Sciences, Tulane University, 1440 Canal Street, Suite 2100, \\ New Orleans, LA 70112, USA; sshercha@tulane.edu \\ 5 Institute of Medicine, Tribhuvan University, Maharajgunj, Kathmandu 1524, Nepal; \\ jeevanbsherchand@gmail.com \\ * Correspondence: eharamoto@yamanashi.ac.jp; Tel.: +81-55-220-8725
}

Received: 28 December 2019; Accepted: 4 February 2020; Published: 7 February 2020

check for updates

\begin{abstract}
Urban rivers affected by anthropogenic activities can act as reservoirs of antibiotic resistance genes (ARGs). This study aimed to describe the occurrence of selected ARGs (bla $a_{\mathrm{TEM}}, \operatorname{ermF}, \operatorname{mec} A$, and tet $A$ ) and a class 1 integron (intI1) in an urban river in Nepal. A total of 18 water samples were collected periodically from upstream, midstream, and downstream sites along the Bagmati River over a 1-year period. All ARGs except mecA and intI1 were consistently detected by a quantitative polymerase chain reaction in the midstream and downstream sites, with concentrations ranging from 3.1 to $7.8 \log$ copies/mL. ARG abundance was significantly lower at the upstream site $(p<0.05)$, reflecting the impact of anthropogenic activities on increasing concentrations of ARGs at midstream and downstream sites. Our findings demonstrate the presence of clinically relevant ARGs in the urban river water of Nepal, suggesting a need for mitigating strategies to prevent the spread of antibiotic resistance in the environment.
\end{abstract}

Keywords: antibiotic resistance gene; integron; quantitative PCR; river water

\section{Introduction}

The majority of the antibiotics used to treat humans and animals are excreted and released into aquatic environments via sewage [1]. The release of antibiotics, even at lower concentrations, can promote the development and dissemination of antibiotic resistance genes (ARGs) [2]. ARGs can be horizontally transferred to different pathological bacterial strains by mobile genetic elements (MGEs), spreading antibiotic resistance [3]. Class 1 integrons are such bacterial MGEs with an established role in the transfer of ARGs [4].

Various studies have shown that urban rivers prone to anthropogenic activities and receiving effluents from wastewater treatment plants (WWTPs) act as reservoirs of ARGs and MGEs [5,6]. A cross-sectional study on the presence and removal of ARGs during wastewater treatment concluded that WWTPs reduce ARGs, but significant concentrations of ARGs are still discharged into wastewater-receiving water bodies [7]. ARGs, now considered as emerging contaminants [8], are more likely to pollute urban riverine systems in developing countries where wastewater is insufficiently treated or is directly discharged into rivers. 
The Bagmati River in the Kathmandu Valley, Nepal, is an example of such an urban river polluted with untreated sewage [9]. It flows from north to south in the Kathmandu Valley, passing through the densely populated region. Previous studies have reported a degraded microbiological quality of water and showed that the Bagmati River is a reservoir of pathogenic bacteria, viruses, and protozoa [10-12]. However, studies regarding the detection of clinically relevant ARGs and MGEs have not been published.

Based on this knowledge, this study aimed to assess the presence of ARGs and a class 1 integron at different sites along the Bagmati River. Four clinically relevant ARGs (bla $\mathrm{TEM}$, ermF, mec $A$, and tet $A$ ) conferring resistance to commonly used antibiotics in this region [13] were selected for this study.

\section{Materials and Methods}

\subsection{Sample Collection and Extraction of Bacterial DNA}

As reported previously [11,12], 100-mL river water samples were collected in sterile bottles once every 2 months between November 2015 and September 2016 from Sundarijal (upstream), Thapathali (midstream), and Chovar (downstream), as shown in Figure 1. Land cover usage details on the map were based on a previously conducted study [14]. Ten milliliters of each sample was filtered through a sterile disposable filter unit (pore size, $0.22 \mu \mathrm{m}$; diameter, $47 \mathrm{~mm}$; Nalgene, Tokyo, Japan) and bacterial DNA was extracted from the membrane filter using CicaGeneus DNA extraction reagent (Kanto Chemical, Tokyo, Japan).

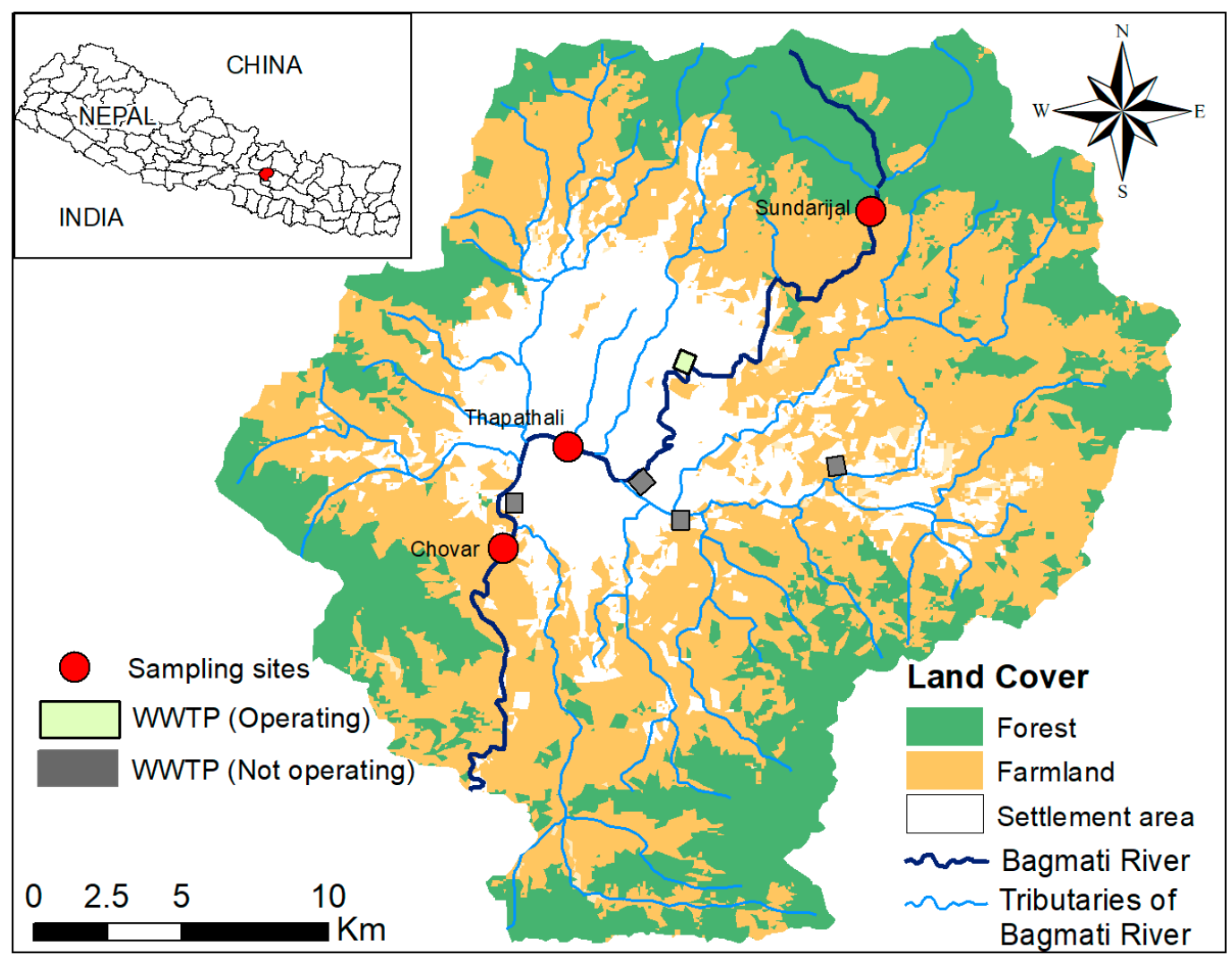

Figure 1. Locations of sampling sites with land cover usage in the Kathmandu Valley.

\subsection{Quantitative Polymerase Chain Reaction ( $q P C R$ )}

The extracted bacterial DNA was serially diluted in 10-fold dilutions $\left(10^{-1}\right.$ and $\left.10^{-2}\right)$ depending on the primer set and was subjected to qPCR using a StepOne Plus Real-Time PCR system (Applied Biosystems, Foster City, CA, USA) and an ABI Power Sybr PCR mix (Applied Biosystems). Forward 
and reverse primers and thermal cycling conditions were followed according to previously published

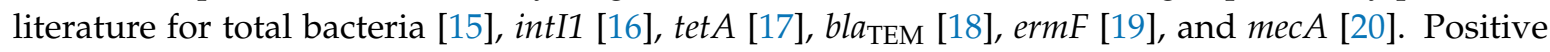
controls were included in each assay using previously collected environmental or clinical isolates harboring the respective ARGs. Inhibition controls comprised the spiking of positive-control DNA into serial dilutions of template DNA. PCR-grade water was used to prepare negative controls. All assays were conducted in duplicates. Amplification products were subjected to melting-curve analysis and were quantified using a six-point 10 -fold standard curve.

\subsection{Statistical Analysis}

The concentrations of total bacteria, ARGs, and intI1 were expressed as log values. For samples below the limit of detection (LOD), one-tenth of the LOD values (1.7 log copies/mL for tet $A$ and $2.7 \log$ copies/mL for other ARGs and intI1) were used for statistical analysis. A one-way analysis of variance followed by a Tukey-Kramer Post Hoc test was used to evaluate the significance of differences in total bacteria, ARGs, and intI1 concentrations at the three sample collection sites using Microsoft Excel 2016 (Redmond, WA, USA). Spearman's correlation was conducted with R statistical software, version 3.6.1, using $\mathrm{R}$ studio to determine the relationship between the abundance of total bacteria, intI1, ARGs, and Escherichia coli. A $p$-value of $<0.05$ was considered significant.

\section{Results}

\subsection{Detection of Total Bacteria, ARGs, and intI1}

Table 1 summarizes the results of detection of ARGs and intI1 in the river water samples. Of the six samples from Sundarijal, tet $A$ was detected only in one sample $(17 \%)$, whereas $b l a_{\mathrm{TEM}}$, ermF, and intI1 were detected in two samples (33\%). In contrast, mec $A$ was not detected at any site, and bla ${ }_{\mathrm{TEM}}$, ermF, tet $A$, and intI1 were detected in all samples from Thapathali and Chovar.

Table 1. Positive ratios of antibiotic resistance genes (ARGs) and intI1 in river water samples.

\begin{tabular}{ccccc}
\hline \multirow{2}{*}{ ARGs/MGE } & \multicolumn{4}{c}{ Number of Positive Samples (\%) } \\
\cline { 2 - 5 } & Sundarijal (n = 6) & Thapathali (n = 6) & Chovar (n=6) & Total (n = 18) \\
\hline bla TEM $_{\text {ermF }}$ & $2(33 \%)$ & $6(100 \%)$ & $6(100 \%)$ & $14(78 \%)$ \\
mecA & $2(33 \%)$ & $6(100 \%)$ & $6(100 \%)$ & $14(78 \%)$ \\
tet $A$ & $0(0 \%)$ & $0(0 \%)$ & $0(0 \%)$ & $0(0 \%)$ \\
intI1 & $1(17 \%)$ & $6(100 \%)$ & $6(100 \%)$ & $13(72 \%)$ \\
\hline
\end{tabular}

The concentrations of total bacteria $(7.1 \pm 0.9 \log$ copies $/ \mathrm{mL}), b l a_{\mathrm{TEM}}(4.1 \pm 2.0 \log$ copies $/ \mathrm{mL})$, $\operatorname{ermF}(3.8 \pm 1.7 \log$ copies $/ \mathrm{mL}), \operatorname{tet} A(2.5 \pm 1.7 \log$ copies $/ \mathrm{mL})$, and intI1 $(3.4 \pm 1.4 \log \mathrm{copies} / \mathrm{mL})$ at the upstream site were significantly lower than those of total bacteria $(8.6 \pm 0.5 \log$ copies $/ \mathrm{mL}), b l a_{\mathrm{TEM}}$ $(6.8 \pm 0.7 \log$ copies $/ \mathrm{mL}), e r m F(6.6 \pm 0.6 \log$ copies $/ \mathrm{mL})$, tet $A(5.9 \pm 0.6 \log$ copies $/ \mathrm{mL})$, and intI1 $(5.6 \pm 0.6 \log$ copies $/ \mathrm{mL})$ observed at the midstream site $(p<0.05)$. However, concentrations at the downstream site did not differ significantly $(p>0.05)$ from those at the midstream site (Figure 2). 


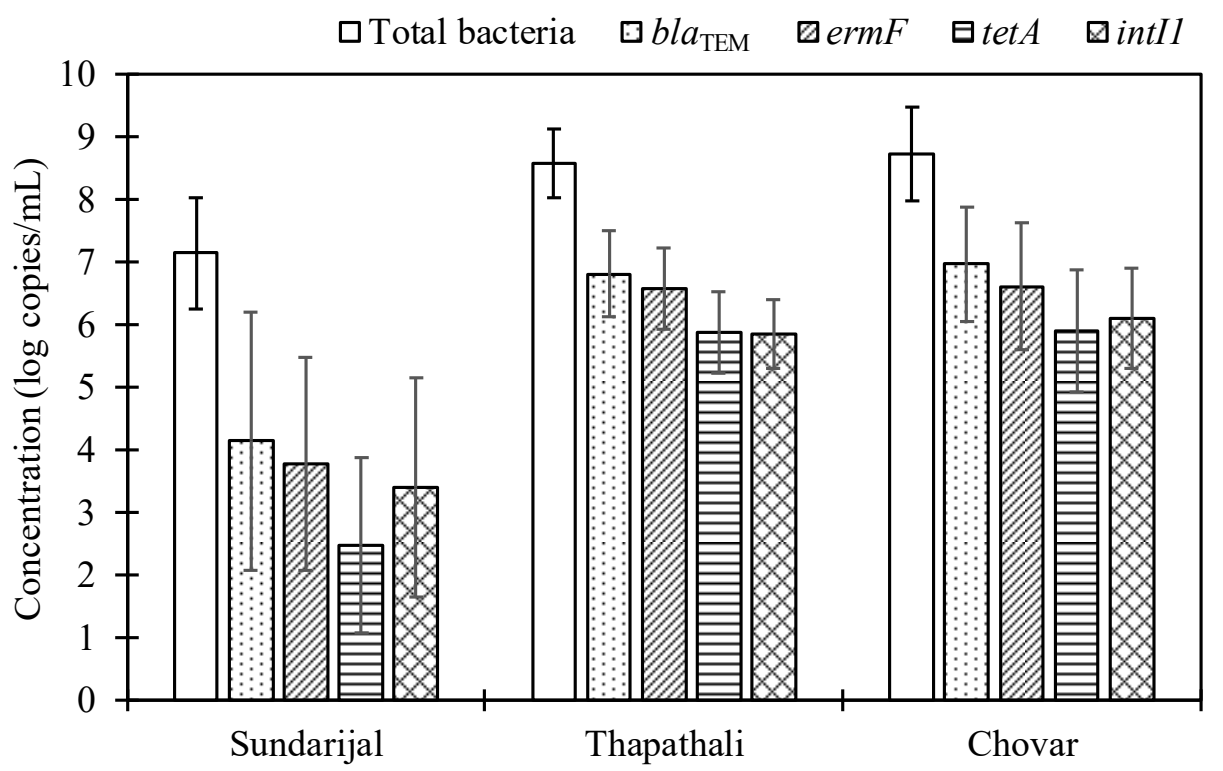

Figure 2. Concentrations of total bacteria, ARGs, and intI1 in the river water samples.

\subsection{Correlation between Concentrations of Total Bacteria, E. coli, ARGs, and intI1}

As shown in Table 2, significant positive correlations were observed between concentrations of intI1 and ARGs $(r \geq 0.94, p<0.05)$ and between total bacteria and ARGs or intI1 $(r \geq 0.91, p<0.05)$. Using data from Tandukar et al. (2018) [12], correlation analysis among concentrations of E. coli, total coliforms, and ARGs or intI1 also demonstrated a strong positive correlation $(r \geq 0.54, p<0.05)$.

Table 2. Correlations among total bacteria, E. coli, ARGs, and intI1.

\begin{tabular}{ccccc}
\hline \multirow{2}{*}{ Bacteria/MGE } & \multicolumn{4}{c}{$r$ Value } \\
\cline { 2 - 5 } & bla $\boldsymbol{a}_{\text {TEM }}$ & tet $\boldsymbol{A}$ & $\boldsymbol{e r m F}$ & intI1 \\
\hline E. coli $^{\#}$ & $0.87^{*}$ & $0.94^{*}$ & $0.93^{*}$ & $0.90^{*}$ \\
Total Bacteria & $0.91^{*}$ & $0.98^{*}$ & $0.95^{*}$ & $0.97^{*}$ \\
Total coliforms & $0.54^{*}$ & $0.57^{*}$ & $0.58^{*}$ & $0.61^{*}$ \\
intI1 & $0.94^{*}$ & $0.97^{*}$ & $0.95^{*}$ & - \\
\hline
\end{tabular}

" Data from Tandukar et al. (2018) [12]. ${ }^{*} p<0.05$.

\section{Discussion}

To the best of our knowledge, this study is the first to report the presence of ARGs and MGE in an aquatic environment in Nepal. The abundance of microbial contaminants, such as bla $a_{\mathrm{TEM}}$, tet $A$, and intI1, found in our study was comparatively higher than that reported in studies conducted in Japan [5] and China [21]. This could be explained by direct hospital and household discharges and drainage from nonfunctioning WWTPs into the Bagmati River. Interestingly, mecA was not detected in any of the river water samples tested. This result is in accordance with a previous study conducted in Germany that demonstrated detectable amounts of mecA only in clinical wastewater [22]. mecA is staphylococci-specific [23], and Staphylococcus belongs to phylum Firmicutes [24]. Sequencing results of the same samples demonstrate that Firmicutes accounts for only $6 \%-15 \%$ of the bacterial community [11]. The lower abundance of Staphylococcus in river water and the incapability of mecA to spread along wastewater, as reported previously [23], may have resulted in the failure to detect mecA in our samples. Lower concentrations of ARGs at the upstream site compared with mid and downstream sites may be attributed to the increase in the number of houses draining untreated sewage farther downstream. Fecal pollution resulting from sewage discharge has been found to be the major 
factor determining the abundance of ARGs [25]. These findings show that anthropogenic activities promote the dissemination of ARGs in the environment [26].

The significant positive correlation observed among ARGs, intI1, total bacteria, and E. coli was consistent with a study conducted in central Europe [27]. As discussed previously, this finding may indicate origination from a common source and release into the receiving river via a common carrier [27]. E. coli, with an ability to accumulate ARGs through horizontal gene transfer [28], could be the major bacterium harboring these ARGs and MGE. Likewise, strong positive correlations between intI1 and ARGs are also in agreement with a prior study that indicated that ARGs were possibly spread by the transfer of class I integrons [6]. This result further supports the use of intI1 as an indicator of antibiotic resistance in aquatic environments [29].

The people in the Kathmandu Valley use groundwater for domestic purposes [30] and river water for irrigation [31]. The interaction of groundwater and river water in Kathmandu [32] increases the probability of groundwater pollution with ARGs. Without any guidelines for the safe use of water polluted with ARGs, these sources of water are a probable source of antibiotic resistance in the Bagmati River basin. However, the detection of ARGs doesn't always mean their transfer occurs in the aquatic environment. Future studies should focus on assessing the suitability of the aquatic environment to transfer these ARGs to potential pathogenic bacteria.

\section{Conclusions}

In summary, three ARGs and intI1 were detected with concentrations ranging from 3.1 to 7.8 log copies/mL at three sites along the Bagmati River. The significant positive correlation between the abundance of ARGs and intI1 suggests the use of intI1 as an indicator of antibiotic resistance in the environment. In Nepal, studies regarding antibiotic resistance are limited to clinical human samples. The detection of clinically relevant ARGs and MGE in an urban river in Nepal indicates a need to monitor antibiotic resistance in the environment.

Author Contributions: Conceptualization, O.T., J.B.S. and E.H.; methodology, S.T., J.P.B. and S.P.S.; validation, J.P.B., S.P.S. and E.H.; formal analysis, O.T.; visualization, O.T. and E.H.; writing-original draft preparation, O.T.; writing-review and editing, S.T., J.P.B., J.B.S., S.P.S. and E.H.; supervision, J.B.S., E.H.; funding acquisition, E.H. All authors have read and agreed to the published version of the manuscript.

Funding: This study was supported by Kurita Water and Environment Foundation, the Science and Technology Research Partnership for Sustainable Development (SATREPS) program of Japan International Cooperation Agency (JICA) and Japan Science and Technology Agency (JST), entitled "Hydro-microbiological Approach for Water Security in Kathmandu Valley, Nepal", and the Japan Society for the Promotion of Science (JSPS) through Fund for the Promotion of Joint International Research (Fostering Joint International Research (B)) (grant number JP18KK0297).

Conflicts of Interest: The authors declare no conflict of interest.

\section{References}

1. Kümmerer, K. Promoting resistance by the emission of antibiotics from hospitals and households into effluent. Clin. Microbiol. Infect. 2003, 9, 1203-1214. [CrossRef] [PubMed]

2. Gullberg, E.; Cao, S.; Berg, O.G.; Ilbäck, C.; Sandegren, L.; Hughes, D.; Andersson, D.I. Selection of resistant bacteria at very low antibiotic concentrations. PLoS Pathog. 2011, 7. [CrossRef] [PubMed]

3. Partridge, S.R.; Kwong, S.M.; Firth, N.; Jensen, S.O. Mobile genetic elements associated with antimicrobial resistance. Clin. Microbiol. Rev. 2018, 31, 1-61. [CrossRef] [PubMed]

4. Hardwick, S.A.; Stokes, H.W.; Findlay, S.; Taylor, M.; Gillings, M.R. Quantification of class 1 integron abundance in natural environments using real-time quantitative PCR. FEMS Microbiol. Lett. 2008, 278, 207-212. [CrossRef]

5. Nguyen, T.N.; Kasuga, I.; Liu, M.; Katayama, H. Occurrence of antibiotic resistance genes as emerging contaminants in watersheds of Tama River and Lake Kasumigaura in Japan. IOP Conf. Ser. Earth Environ. Sci. 2019, 266, 4-12. [CrossRef] 
6. Jia, J.; Guan, Y.; Cheng, M.; Chen, H.; He, J.; Wang, S.; Wang, Z. Occurrence and distribution of antibiotics and antibiotic resistance genes in Ba River, China. Sci. Total Environ. 2018, 642, 1136-1144. [CrossRef]

7. Pallares-Vega, R.; Blaak, H.; van der Plaats, R.; de Roda Husman, A.M.; Hernandez Leal, L.; van Loosdrecht, M.C.M.; Weissbrodt, D.G.; Schmitt, H. Determinants of presence and removal of antibiotic resistance genes during WWTP treatment: A cross-sectional study. Water Res. 2019, 161, 319-328. [CrossRef]

8. Pruden, A.; Pei, R.; Storteboom, H.; Carlson, K.H. Antibiotic resistance genes as emerging contaminants: Studies in northern Colorado. Environ. Sci. Technol. 2006, 40, 7445-7450. [CrossRef]

9. Mishra, B.K.; Regmi, R.K.; Masago, Y.; Fukushi, K.; Kumar, P.; Saraswat, C. Assessment of Bagmati river pollution in Kathmandu Valley: Scenario-based modeling and analysis for sustainable urban development. Sustain. Water Qual. Ecol. 2017, 9-10, 67-77. [CrossRef]

10. Haramoto, E.; Yamada, K.; Nishida, K. Prevalence of protozoa, viruses, coliphages and indicator bacteria in groundwater and river water in the Kathmandu Valley, Nepal. Trans. R. Soc. Trop. Med. Hyg. 2011, 105, 711-716. [CrossRef]

11. Ghaju Shrestha, R.; Tandukar, S.; Bhandari, D.; Sherchan, S.P.; Tanaka, Y.; Sherchand, J.B.; Haramoto, E. Prevalence of Arcobacter and other pathogenic bacteria in river water in Nepal. Water 2019, 11, 1416. [CrossRef]

12. Tandukar, S.; Sherchand, J.; Bhandari, D.; Sherchan, S.; Malla, B.; Ghaju Shrestha, R.; Haramoto, E. Presence of human enteric viruses, protozoa, and indicators of pathogens in the Bagmati River, Nepal. Pathogens 2018, 7, 38. [CrossRef]

13. Acharya, K.; Wilson, R.T. Antimicrobial Resistance in Nepal. Front. Med. 2019, 6, 105. [CrossRef] [PubMed]

14. Ishtiaque, A.; Shrestha, M.; Chhetri, N. Rapid Urban Growth in the Kathmandu Valley, Nepal: Monitoring Land Use Land Cover Dynamics of a Himalayan City with Landsat Imageries. Environments 2017, 4, 72. [CrossRef]

15. Nadkarni, M.A.; Martin, F.E.; Jacques, N.A.; Hunter, N. Determination of bacterial load by real-time PCR using a broad-range (universal) probe and primers set. Microbiology 2002, 148, 257-266. [CrossRef] [PubMed]

16. Barraud, O.; Baclet, M.C.; Denis, F.; Ploy, M.C. Quantitative multiplex real-time PCR for detecting class 1, 2 and 3 integrons. J. Antimicrob. Chemother. 2010, 65, 1642-1645. [CrossRef]

17. Fan, W.; Hamilton, T.; Webster-Sesay, S.; Nikolich, M.P.; Lindler, L.E. Multiplex real-time SYBR Green I PCR assay for detection of tetracycline efflux genes of gram-negative bacteria. Mol. Cell Probes 2007, 21, 245-256. [CrossRef]

18. Lachmayr, K.L.; Cavanaugh, C.M.; Kerkhof, L.J.; DiRienzo, A.G.; Ford, T.E. Quantifying nonspecific tem $\beta$-lactamase (blatem) genes in a wastewater stream. Appl. Environ. Microbiol. 2009, 75, 203-211. [CrossRef]

19. Chen, J.; Yu, Z.; Michel, F.C.; Wittum, T.; Morrison, M. Development and application of real-time PCR assays for quantification of erm genes conferring resistance to macrolides-lincosamides-streptogramin B in livestock manure and manure management systems. Appl. Environ. Microbiol. 2007, 73, 4407-4416. [CrossRef]

20. Sabet, N.S.; Subramaniam, G.; Navaratnam, P.; Sekaran, S.D. Detection of methicillin- and aminoglycoside-resistant genes and simultaneous identification of S. aureus using triplex real-time PCR Taqman assay. J. Microbiol. Methods 2007, 68, 157-162. [CrossRef]

21. Guan, Y.; Jia, J.; Wu, L.; Xue, X.; Zhang, G.; Wang, Z. Analysis of bacterial community characteristics, abundance of antibiotics and antibiotic resistance genes along a pollution gradient of Ba River in Xi'an, China. Front. Microbiol. 2018, 9, 12. [CrossRef] [PubMed]

22. Schwartz, T.; Kohnen, W.; Jansen, B.; Obst, U. Detection of antibiotic resistant bacteria and their resistance genes in wastewater, surface water and drinking water biofilms. FEMS Microbiol. Ecol. 2003, 43, 325-335. [CrossRef]

23. Volkmann, H.; Schwartz, T.; Bischoff, P.; Kirchen, S.; Obst, U. Detection of clinically relevant antibiotic-resistance genes in municipal wastewater using real-time PCR (TaqMan). J. Microbiol. Methods 2004, 56, 277-286. [CrossRef] [PubMed]

24. Lanza, V.; Tedim, A.; Martínez, J.; Baquero, F.; Coque, T. The plasmidome of firmicutes: Impact on the emergence and the spread of resistance to antimicrobials. Microbiol. Spectr. 2015, 3. [CrossRef] [PubMed]

25. Karkman, A.; Pärnänen, K.; Larsson, D.G.J. Fecal pollution can explain antibiotic resistance gene abundances in anthropogenically impacted environments. Nat. Commun. 2019, 10, 80. [CrossRef] [PubMed] 
26. Tacão, M.; Correia, A.; Henriques, I. Resistance to broad-spectrum antibiotics in aquatic systems: Anthropogenic activities modulate the dissemination of blaCTX-M-like genes. Appl. Environ. Microbiol. 2012, 78, 4134-4140. [CrossRef] [PubMed]

27. Devarajan, N.; Laffite, A.; Graham, N.D.; Meijer, M.; Prabakar, K.; Mubedi, J.I.; Elongo, V.; Mpiana, P.T.; Ibelings, B.W.; Wildi, W.; et al. Accumulation of clinically relevant antibiotic-resistance genes, bacterial load, and metals in freshwater lake sediments in central Europe. Environ. Sci. Technol. 2015, 49, 6528-6537. [CrossRef]

28. Poirel, L.; Madec, J.-Y.; Lupo, A.; Schink, A.-K.; Kieffer, N.; Nordmann, P.; Schwarz, S. Antimicrobial resistance in Escherichia coli. Microbiol. Spectr. 2018, 6. [CrossRef]

29. Lucassen, R.; Rehberg, L.; Heyden, M.; Bockmuhl, D. Strong correlation of total phenotypic resistance of samples from household environments and the prevalence of class 1 integrons suggests for the use of the relative prevalence of intI1 as a screening tool for multi-resistance. PLoS ONE 2019, 14, e218277. [CrossRef]

30. Shrestha, S.; Aihara, Y.; Bhattarai, A.P.; Bista, N.; Rajbhandari, S.; Kondo, N.; Kazama, F.; Nishida, K.; Shindo, J. Dynamics of domesticwater consumption in the urban area of the Kathmandu Valley: Situation analysis pre and post 2015 Gorkha Earthquake. Water 2017, 9, 222. [CrossRef]

31. Rutkowski, T.; Raschid-Sally, L.; Buechler, S. Wastewater irrigation in the developing World-Two case studies from the Kathmandu Valley in Nepal. Agric. Water Manag. 2007, 88, 83-91. [CrossRef]

32. Bajracharya, R.; Nakamura, T.; Shakya, B.M.; Nishida, K.; Das Shrestha, S.; Tamrakar, N.K. Identification of river water and groundwater interaction at central part of the Kathmandu valley, Nepal using stable isotope tracers. Int. J. Adv. Sci. Technol. Res. 2018, 3, 29-41. [CrossRef]

(C) 2020 by the authors. Licensee MDPI, Basel, Switzerland. This article is an open access article distributed under the terms and conditions of the Creative Commons Attribution (CC BY) license (http://creativecommons.org/licenses/by/4.0/). 